\title{
TRABALHOS PUBLICADOS PELOS PROFESSORES
}

\section{Prof. Aloísio Surgik}

Livro: Lineamento do Processo Civil Romano.

Prof. Edson Ribas Malachini

Livro: Ato Administrativo, Juruá Editora.

Profs. Francisco José Ferreira Muniz e José Lamartine Corrêa de Oliveira Lyra, "in memoriam".

Livro: Curso de Direito da Família, Fabris, 1990.

Prof. Nilton Bussi

Artigo: Juizados Especiais de Pequenas Causas Criminais, Jornal Gazeta do Povo.

Prof. Jacinto Nelson de Miranda Coutinho

Artigos: Telefestivais de prêmios e bingões - uma solução jurídica. Juruá Editora.

Considerações sobre a prisão temporária, Boletim Bonijuris.

$\mathrm{O}$ ato administrativo de instauração de inquérito policial. Jurisprudência brasileira criminal, Juruá Editora.

Prof. Rolf Koerner Junior

Artigos: Tóxicos. A legislação atual e futura do Brasil, Revista Themis.

Erro médico profissional e culpa grosseira, Revista Themis.

Prof. Francisco Accioly R. da Costa Neto

Artigo: A dignidade constitucional dos advogados. Jornal dos Advogaods Trabalhistas.

Prof. Manoel Caetano Ferreira Filho.

Livro: A Preclusão no Direito Processual Civil. 
Prof. Clèmerson Merlin Clève

Livro: As Medidas Provisórias e a Constituição Federal de 1988, Juruá Editora.

Artigo: Sobre o direito e os direitos: o jurídico como espaço de luta.

Revista da Associação dos Magistrados do Paraná, v. 008, ano 34, Curitiba-PR.

Prof. João Régis Fassbender Teixeira

Livro: Curso de Direito Constitucional do Trabalho. LTR Editora, São Paulo.

Prof. René Ariel Dotti

Artigo: Da defesa do consumidor em juízo. Editora Forense, Rio de Janeiro.

Prof. Jacinto Nelson de Miranda Coutinho

Artigos: Direito alternativo: têm razão os juízes gaúchos. Boletim Bonijuris, n. 74 . Curitiba-PR.

Por um direito de libertação do direito. Revista do Instituto dos Advogados do Paraná, n. ${ }^{\circ}$ 16. Curitiba-PR. 